Antoni Górski

Sąd Najwyższy

\title{
SŁUSZNOŚĆ W ORZEKANIU SĘDZIEGO CYWILISTY
}

O słuszności w orzekaniu można mówić w dwóch aspektach. Po pierwsze, jako o zasadzie bądź przesłance wyrokowania sformułowanych w przepisach prawa i po wtóre, jako o jednej z najważniejszych dyrektyw sędziowskiego orzekania w sprawach cywilnych. Słuszność, jako jedną z zasad odpowiedzialności deliktowej, omówiła pani sędzia profesor Helena Ciepła. Warto wskazać, że słuszność jest także przesłanką możliwości przyznania świadczeń odszkodowawczych w niektórych typach odpowiedzialności kontraktowej. I tak np. w art. $764^{3} \S 1$ k.c. przewidziana została możliwość dochodzenia tzw. świadczenia wyrównawczego już po rozwiązaniu umowy agencyjnej, jeżeli w czasie jej trwania agent pozyskał nowych klientów lub doprowadził do istotnego wzrostu obrotów z dotychczasowymi klientami, a dający zlecenie czerpie nadal znaczące korzyści z umów z klientami. Roszczenie to przysługuje agentowi, jeżeli, biorąc pod uwagę wszystkie okoliczności, a zwłaszcza utratę przez agenta prowizji od umów zawartych przez dającego zlecenie z tymi klientami, przemawiają za tym względy słuszności. Według zasad słuszności ma być podzielona także prowizja pomiędzy poprzednim i obecnym agentem w sytuacji uregulowanej w art. $761^{2}$ k.c. $Z$ kolei zgodnie $\mathrm{z}$ art. $827 \S 2 \mathrm{zd}$. drugie k.c., w razie wyrządzenia szkody przez poszkodowanego na skutek rażącego niedbalstwa, ubezpieczyciel może ponosić odpowiedzialność, jeżeli przemawiają za tym względy słuszności.

Niezależnie od tych przykładów regulacji prawnych, w których słuszność jest powołana wprost jako zasada lub przesłanka odpowiedzialności odszkodowawczej, stanowi ona podstawę konstrukcyjną całych instytucji prawnych o fundamentalnym znaczeniu w dziedzinie cywilistyki, takich jak przykładowo: nadużycie prawa (art. 5 k.c.), wykładnia oświadczeń woli (art. $65 \S 1$ k.c.), granice korzystania z prawa własności (art. 140 k.c.), przyczynienie poszkodowanego do powstania lub zwiększenia szkody (art. 362 k.c.), czy rozłożenie na raty lub droczenie wykonania świadczenia (art. 322 k.p.c.). Słuszność jest też jedną z podstawowych miar przy określaniu wysokości zadośćuczynienia na każdej z przewidujących to świadczenie podstaw prawnych oraz przy miarkowaniu odszkodowania (art. 440 k.c.). Stanowi też istotną 
przesłankę przyznania powodowi odpowiedniej sumy, kiedy ścisłe udowodnienie żądania jest niemożliwe lub nader utrudnione (art. $322 \mathrm{i}$ art. $505^{6}$ k.p.c.).

Wskazane przykłady regulacji kodeksowych odwołują się wprost lub pośrednio do słuszności, jako zasady odpowiedzialności, albo jako do ważnej przesłanki wyrokowania. Słuszność stanowi jednak przede wszystkim jedną z podstawowych kategorii, na których zbudowany jest cały system prawa cywilnego, stąd też należy ona do najważniejszych dyrektyw orzekania we wszystkich sprawach cywilnych, w których występuje margines swobody oceny.

Orzekanie jest roboczym określeniem merytorycznej pracy sędziego; nieco bardziej odświętnie nazywa się ją wymierzaniem sprawiedliwości. Według Arystotelesa słuszność (epikeia) jest niezbędnym składnikiem sprawiedliwości, stanowiącym jej najdoskonalszą formę i przejaw. ${ }^{1}$ Czuję się zwolniony od przytaczania wielości definicji pojęcia słuszności, gdyż ma to być przedmiotem odrębnego referatu. Osobiście uważam, że w tym arystotelowskim określeniu jest najwięcej racji. Słuszność (łac. aequitas) należy bowiem do najważniejszych czynników konstruujących pojęcie sprawiedliwości, a ponadto jest tej sprawiedliwości podstawową miarą. Sprawiedliwość jest przy tym nieodzownym składnikiem budowy prawidłowego ładu państwowego i społecznego. $Z$ tego punktu widzenia pojęcie państwa prawnego, które tak często eksponujemy, ma sens, jeśli państwo to urzeczywistnia zasady sprawiedliwości, a więc kiedy można określić je jednocześnie mianem państwa sprawiedliwego. Nie bez powodu w inwokacji do naszej Konstytucji ustrojodawca odwołuje się do idei sprawiedliwości dwukrotnie, a w art. 2 ustawy zasadniczej deklarując, że Rzeczypospolita Polska jest demokratycznym państwem prawnym, nakłada obowiązek realizacji przez wszystkie organy publiczne zasady sprawiedliwości społecznej. Szczególna rola w tym zakresie przypada sądom. Konstytucja, regulując kompetencje najważniejszych organów państwa, określa bardzo ogólnie sposób ich realizacji. Mają one działać na podstawie i w granicach prawa (art. 7), rzetelnie i sprawnie, z poszanowaniem przyrodzonej godności człowieka, jego prawa do wolności i solidarności z innymi ludźmi (z inwokacji do ustawy zasadniczej). Dodatkowe i wyjątkowe wymagania ustrojodawca postawił wobec sądów, formułując je w art. 45 za pomocą aż siedmiu przymiotników, eksponując na pierwszym miejscu obowiązek sprawiedliwego rozpoznania sprawy. W tym wyraża się istota działalności sądów, którą jest wymierzanie sprawiedliwości. Wykonując tę podstawową funkcję, sądy mają możliwość pośredniego oddziaływania na sposób stosowania prawa w naszym kraju przez pozostałe organy oraz przez obywateli. Bierze się to stąd, że sądy w naszym państwie są najważniejszym interpretatorem prawa, ustalającym w sposób ostateczny i wiążący treść i znaczenie obowiązujących przepisów, kończąc niejako w ten sposób cały proces tworzenia prawa. Tę doniosłą rolę sądów podkreślał wielokrotnie Trybunał Konstytucyjny. Między innymi w wyroku z dnia 13 kwietnia 
1999 r., K 36/98² Trybunał stwierdził, że ,jednym z rudymentów zasady zaufania obywatela do państwa i stanowionego przez nie prawa jest to, że obywatel może zakładać, iż treść obowiązującego prawa jest dokładnie taka, jak to zostało ustalone przez sądy, zwłaszcza gdy ustalenie to zostaje dokonane przez Sąd Najwyższy (...), albo znajduje wyraz w jednolicie ustabilizowanym stanowisku judykatury".

Wypełnienie tej roli w sposób należyty jest możliwe pod warunkiem posiadania przez sędziów odpowiednich predyspozycji w postaci właściwego wyczulenia na zasady słuszności i sprawiedliwości, które Fryderyk Zoll określał mianem ,zdolności odnajdywania prawa sprawiedliwego, prawego". Instrumentem, za pomocą którego możliwe jest realizowanie tego zadania, jest sędziowskie sumienie. Zgodnie $\mathrm{z}$ ustawową rotą ślubowania sędziowskiego, zawartą $\mathrm{w}$ art. 66 usp, sumienie jest - obok wymogu zgodności z prawem - podstawową instancją, według której należy sprawować wymiar sprawiedliwości. Trzeba dodać, że formuła tego ślubowania nawiązuje do treści najstarszych przysiąg sędziowskich. I tak sędziowie w starożytnej Grecji przysięgali, że będą wyrokować zgodnie z ustawami (uchwałami) ludu ateńskiego i Rady, a jeśliby nie było ustawy, zgodnie z moim poczuciem sprawiedliwości ${ }^{4}(. .$.$) . Jeszcze wyraziściej akcentowała znaczenie sumienia przysięga sędziów$ w dawnym Egipcie, gdzie sędziowie zobowiązywali się, że „nie zboczą od swego sumienia, choćby nawet królowie sami im to rozkazywali5".

Tak więc sędzia $\mathrm{z}$ mocy ustawy obowiązany jest $\mathrm{w}$ orzekaniu kierować się nie tylko literą prawa, ale także zasadami słuszności. Katalog tych zasad jest częścią zasad moralnych obowiązujących uczciwych obywateli w danym kręgu kulturowym. Nie siląc się na przytoczenie tego katalogu, warto wspomnieć, że pierwsza zanotowana w Polsce wypowiedź na ten temat pochodzi od błogosławionego Wincentego Kadłubka - kronikarza biskupa. Stwierdził on, że sprawiedliwość powinna polegać na wspomaganiu ei qui minimum potest, a więc tego, który może najmniej, czyli słabszego i ten wymóg słuszności zachowuje aktualność.

Odczytywanie treści prawa według uniwersalnych wartości aksjologicznych jest możliwe przy uwzględnianiu dyrektywy jego wykładni z nachyleniem do człowieka, a więc pro homini. Taka postawa sędziego nawiązuje do maksymy prawa rzymskiego - aequitas praefertur rigori - słuszność przed rygoryzmem (formalizmem) i pozwala mu na przekształcanie lex $\mathrm{w}$ ius, nadając jego pracy prawdziwie twórczy i humanitarny charakter.

\footnotetext{
OTK 1999, nr 3, poz. 40.

F. Zoll, Prawo w zarysie. Część ogólna, t. I, Kraków 1946, s. 53.

M. Kuryłowicz, Prawa antyczne. Wykłady z historii najstarszych prawa świata, Lublin 2006, s. 144.

R. Tokarczuk, Przykazania etyki prawniczej. Księgi myśli, norm i rycin, Kraków 2003, s. 244.
} 


\section{THE PRINCIPLE OF EQUITY IN ADJUDICATING THE JUDGE CIVILIST}

The article discusses equity as a principle, and as a premise of compensatory responsibility. Moreover, the principle of equity is presented as a basis for the construction of institutions such as abuse of a subjective right, the interpretation of a declaration of intent, the boundaries of ownership. The author argues that equity is the foundation of the whole of civil law.

Keywords: the principle of equity, civil law, the court, jurisprudence 